Ю. Б. Ситник ${ }^{1}$, В. В. Стадник ${ }^{2}$

${ }^{1}$ Кропивницька льотна академія Національного авіаційного університету, Кропивницький

${ }^{2}$ Харківський національний університет Повітряних Сил імені Івана Кожедуба, Харків

\title{
ФОРМУВАННЯ ІНФОРМАЦЙНОГО ПОЛЯ В КАБІНІ БОЙОВОГО ЛІТАКА В УМОВАХ ЗАСТОСУВАННЯ ПОТУЖНИХ ВИБУХІВ
}

\begin{abstract}
Підвищення багатофункціональності та характеристик бортового обладнання, збільшення обсягів інформації, що надходить на літак (який в даний час можна вже розглядати як елемент розподіленої інформаційно-ударної системи), а також зовнішні загрози, які можуть виникнути на театрі військових дій, пред'являють більш високі вимоги до відображення інформації і компонуванні кабін бойових літаків. Формування в кабіні літака інформаційного поля для виведення інформації льотчику при виконанні бойового завдання на бомбометання необхідно мати не тільки розраховані параметри області бомбометання з урахуванням типу засобів поразки, швидкості літального апарату, густини повітря та кута пікірування, а і необхідно враховувати рельєф місцевості, протидію об'єктової та зональної системи ППО. Мета статті - розробка методу визначення параметрів небезпечних зон впливу на літальний апарат під час виконання бойового завдання необхідних для надання інформації льотчику в реальному режимі часу на дисплеї в кабіні літака. Висновки. Забезпечення екіпажу виводом даної інформації в кабіні літака на тактичному дисплеї з прив'язкою до супутникової навігаційної системи дає можливість більш ефективно застосовувати засоби поразки, при цьому не входити в зони поразки своїх засобів і ефективно обходити зони поразки ППО противника. Побудова даних зон в трьохвимірному просторі повинно базуватися на автоматичному розрахунку зон поразки виходячи з фактичних параметрів польоту літака, типу авіаційного засобу поразки та типу ППО противника, які будуть протидіяти в заданому районі нанесення удару.
\end{abstract}

Ключов і слова: інформаційне поле, область бомбометання, умови безпеки, літальний апарат, зона впливу, штучний зсув повітряних мас.

\section{Вступ}

Постановка проблеми. Підвищення бойових можливостей тактичної авіації в країнах НАТО пов'язується в першу чергу з поліпшенням льотнотехнічних характеристик перебувають на їі озброєнні літаків. Це досягається як за рахунок вдосконалення аеродинамічних характеристик планерів, силових установок і зброї, так і завдяки застосуванню додаткових, більш складних бортових систем. Використання останніх вимагає установки в кабінах все зростаючої кількості пристроїв відображення інформації та управління.

Найважливішими оперативно-тактичними вимогами, що пред'являються до бойових дій авіації, $\epsilon$ раптовість, точність і своєчасність. Це, в свою чергу, вимагає від екіпажів літальних апаратів вміння точно виходити на задані наземні і морські цілі в строго призначений час, здійснюючи політ по таких траєкторіях, які забезпечують найбільш ефективне виконання поставленого завдання.

Комплекс заходів, що проводяться штурманською службою суб'єкта державної авіації 3 метою досягнення високої точності і надійності повітряної навігації, ефективності і якості бойового (спеціального) застосування, успішного вирішення завдань бойової (спеціальної) підготовки і безпеки польотів - $є$ штурманське забезпечення польотів [1].

Нові інформаційні технології вимагають реорганізації підходів щодо управління та виконання штурманської підготовки льотного складу до виконання поставленого бойового завдання. Тому виникає науково-прикладне завдання, яке полягає у вирішенні протиріччя невідповідності існуючих підходів до підготовки льотного складу в штурманському відношенні, з одного боку, і необхідністю досягнен- ня заданого рівня підготовки в мінімальні часові терміни та відповідною точністю з іншого.

Питання стоїть не тільки в автоматизації штурманських розрахунків перед виконанням польоту [2], а й в отриманні достовірної поточної інформації під час виконання польоту в складних умовах вогневої і інформаційної протидії противника, швидкої зміни оперативно-тактичної та метеорологічної обстановки в районі виконання польоту.

Звідси виникають питання: яку інформацію буде надавати льотчику інформаційне поле в кабіні літака при виконанні бойової задачі? В якому обсязі і як будуть проводитися розрахунки необхідних параметрів?

Аналіз останніх досліджень і публікацій. Сучасні світові тенденції розвитку військової авіації вимагають нових, наукових підходів до організації рівня підготовки льотного складу, що грунтується на аналізі кінцевої мети підготовчого процесу - забезпечення готовності авіаційних частин (підрозділів) 3 високою ефективністю виконувати поставлені бойові завдання [3].

Рівень бортового інтелекту літака в більшому ступені визначається вдосконаленням радіоелектронних засобів, їх можливостями як інформаційних систем і датчиків[4]. Також на результативність бойового застосування значний вплив має бортове радіоелектронне обладнання. Але важлива складова інтелекту бойового літака полягає в спроможності виконувати покладені на авіаційний комплекс функції в протиборстві з противником, умінні перемогти в бою, залишившись неушкодженим в складній тактичній і інформаційній обстановці.

Задачі поточного призначення або корекції цілі функціонуванні, вибору способу доставки цієї цілі, його реалізації вирішуються сумісно екіпажем і апа- 
ратно-програмними засобами бортових систем, основу яких складає алгоритмічне та інформаційне забезпечення бойових дій літака і застосування авіаційного озброєння [5].

Саме алгоритми, реалізовані в програмах бортової цифрової обчислювальної машини верхнього рівня (бойового застосування), сумісно 3 індикаційним полем кабіни літака будують інформаційно-керуюче середовище, в якому вирішаються завдання авіаційного бойового комплексу. Досягнення нових тактикотехнічних можливостей авіаційного комплексу в результаті інтелектуалізації процедур з прийняття рішень, керування і обробки інформації, а також підвищення точнісних характеристик систем комплексу бортового обладнання з використанням нових інформаційних технологій дозволить забезпечити:

- переваги в повітрі за рахунок своєчасного і раціонального застосування керованого озброєння i засобів радіоелектронної протидії;

- ефективну оборону літального апарату від ракет противника класу «повітря-повітря» та зенітних керованих ракет;

- достовірну інформацію про зовнішню обстановку і підказку екіпажу літака про найкращий варіант виконання бойової задачі $з$ урахуванням самозбереження [5].

Відповідно до вимог зарубіжних спеціалістів [6], до розроблювальних перспективних кабін з інтегрованим управлінням і підтримкою прийняття рішення для забезпечення дій багатофункціонального ударного літака пред'являється ряд вимог, із яких відзначається:

- забезпечити льотчику (екіпажу) ситуаційну обізнаність на всіх етапах польоту, на якому театрі військових дій і при будь-якій інтенсивності бойових дій, а також можливість застосування літака в будь-який час доби в простих і складних метеоумовах за рахунок інформації, одержуваної від усіх можливих джерел: бортових датчиків, зовнішніх джерел, включаючи також головки самонаведення керованої високоточної зброї;

- надати допомогу в плануванні виконання бойової задачі та іiі оперативного зміни в реальному масштабі часу, що передбачає наявність апаратури обміну даними, бортової бази даних і бортових експертних систем;

- забезпечити відображення інформації різних форматів і будь-якого обсягу (включаючи, наприклад, фотографію району цілі, отриману з розвідувального космічного апарату або безпілотного літального апарату [7]) і передбачити декілька способів управління бортовим радіоелектронним обладнанням;

- забезпечити виконання маловисотного польоту з обходом перешкод, що також передбачає наявність активних бортових систем 3 низькою ймовірністю перехоплення сигналу, інформаційних баз даних (з місцевістю польотів), системи синтезу тривимірних зображень;

- для забезпечення мінімальної помітності необхідно передбачити введення в бортову обчислювальну (експертну) систему сигнатур літака в інтеpecax підвищення безпеки польоту і ефективності вирішення бойових завдань, також використання сигнатур літаків противника для визначення їх небезпечних зон дії озброєння;

- забезпечення відслідковування напрямку погляду і жестикуляції льотчика за допомогою нейрошоломів та застосування систем додаткової реальності.

Тому розробка і вдосконалення існуючих систем обробки інформації та індикації в кабіні літака має велике значення для збільшення бойової ефективності бойового літака.

Перспективна інформаційно-обчислювальна система бойового літака буде забезпечувати ефективне рішення тактичних задач протиборства 3 противником, задач бойового управління літаком і використанням високоточної зброї класів «повітря-повітря» $\mathrm{i}$ «повітря-поверхня», інформаційне забезпечення бойових режимів польоту з побудовою ситуаційної обізнаності екіпажу як основного елементу всієї системи. Причому інформаційне поле в кабіні літального апарату також повинне надавати інформацію про небезпечні зони впливу авіаційних засобів поразки на літак для забезпечення не попадання в них літака.

Мета статті - розробка методу визначення параметрів небезпечних зон впливу на літальний апарат під час виконання бойового завдання необхідних для надання інформації льотчику в реальному режимі часу на дисплеї в кабіні літака.

\section{Виклад основного матеріалу}

Для формування інформаційного поля в кабіні бойового літака використовуються розрахунки щодо зон ураження засобів ППО противника. Але необхідно також мати обриси небезпечних зон застосування свого авіаційного озброєння для безпечного виходу 3 атаки. Методики розрахунку небезпечних зон застосування авіаційного озброєння були розроблені і використовуються для розрахунків бойового застосування авіації по наземних і повітряних цілях [8].

Питанням безпеки бомбометання завжди приділялося багато уваги. Проте в теперішній час вони придбали особливу актуальність. Це пояснюється використанням при бомбометанні малих та гранично малих висот [9], суттєвим збільшенням кількості авіабомб, які скидаються літаком в одній атаці, а також нанесення бомбардувальних ударів групами літаків по одній і тій самій цілі або по різних, але близько розміщених. Як відомо, вимоги до умов, які б забезпечували високу ефективність та безпеку бомбометання, в деяких випадках являються взаємно протилежними. Тому при плануванні польотів необхідно призначати такі умови скидання авіабомб, котрі, з одного боку, забезпечували досягнення найбільшої ймовірності враження цілі, а з іншого боку повністю виключають можливість пошкодження своїх літаків [10]. Тому постала необхідність у відтворенні на дисплеї льотчика картографічної інформації у 3D з обрисами небезпечних зон застосування авіаційних засобів поразки та протидії систем ППО противника (рис. 1, 2). Перспективним напрямком в області індикації картографічної інформації є створення повністю електронних засобів формування цифрової карти місцевості. 


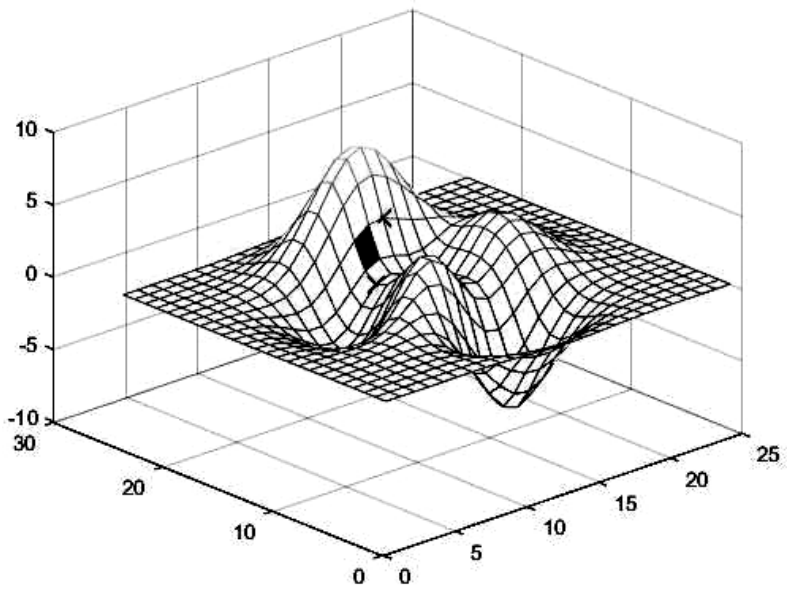

Рис. 1. Тривимірна модель поверхні Землі з нанесенням місця розташування об'єкту нанесення удару

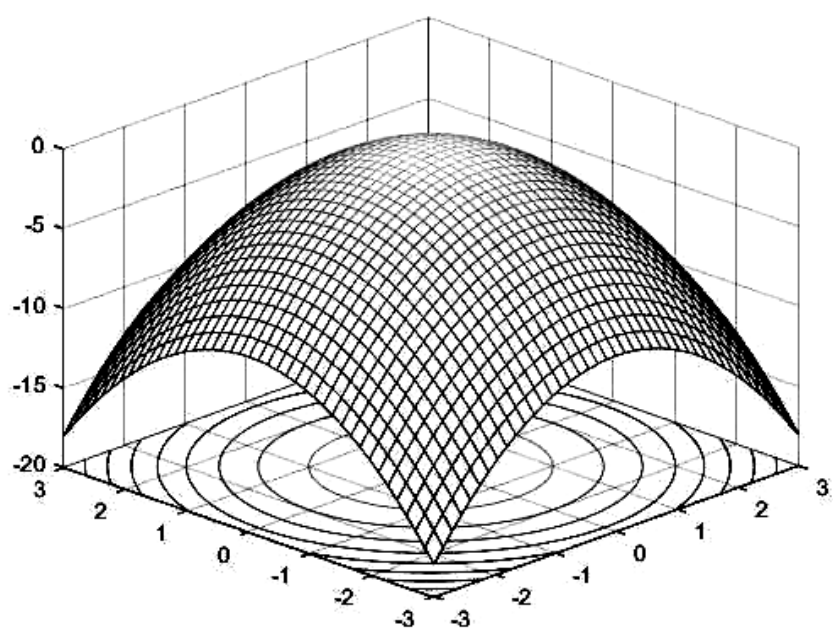

Рис. 2. Формування зони поразки літального апарату при нанесенні удару по наземній цілі

Так, фірма «Хьюз» на замовлення ВВС США розробляє апаратуру ITARS, за допомогою якої картографічна інформація відображається у вигляді тривимірної карти 3 кольоровим кодуванням особливостей рельєфу місцевості, споруд і дерев. Інформація надається льотчику в вигляді карти місцевості або синтезованого ЕОМ схематичного зображення лежачої попереду місцевості, як би видимої з літака. Відтворення здійснюється на індикаторах горизонтальної або вертикальної обстановки або на електроннооптичному індикаторі з відображенням на тлі лобового скла.

На карту можуть бути накладені символи, отримані від РЛС, ІК станції та інших датчиків.

Крім того, картографічна інформація передається на інші системи літака для забезпечення автоматичного польоту в режимі проходження рельєфу місцевості, навігації та застосування зброї.

При виході апарату в район цілі льотчику необхідно мати інформацію про область та оптимальні умови застосування даного засобу.

Окрім цього також розраховується мінімальна відносна висота прольоту перешкод у зоні (районі) виконання спеціальних завдань $\left(\mathrm{OCH}_{3 о н и}\right)$ [11]. Так, наприклад, для розрахунків області та оптимальних умов бомбометання необхідно знати:

- швидкість літака в момент бомбометання, а також траєкторію його польоту після скидання авіабомб;

- висоту цілі над рівнем моря та температуру повітря в районі цілі, необхідних для розрахунку густини повітря;

- основні характеристики авіабомби - масу, площу міделя, балістичні характеристики авіабомби, характеристики іiї гальмівного пристрою, якщо він $\epsilon$, та інше;

- характеристики осколкуватості авіабомби початкову швидкість осколків та іiі залежність від маси осколків і напрямків їх розльоту, закони розподілу осколків по величині маси і напрямкам розльоту, коефіцієнт сили лобового опору осколків та інше.

Область бомбометання (ОБ) при бомбометанні 3 пікірування визначається в координатах:

- D - дальність;

- Н - висота бомбометання;

- $\lambda$ - кут пікірування.

Ближня границя ОБ представляє собою сукупність точок, які розташовані на мінімальних відстанях бомбометання, які, в основному, визначаються:

- умовами безпеки;

- обмеженнями по максимальному перевантаженню та темпу його створення при виводі літака 3 пікірування;

- швидкістю літака на виводі із пікірування;

- технічними характеристиками детонаторів.

За параметр безпеки використовується мінімальна дальність виходу з атаки, яку визначають [7]:

$$
\begin{gathered}
D_{\text {вих }}(\text { Нб })=0,5 \cdot V_{1} \cdot t_{n}+\frac{H_{\sigma}+R_{\text {вив }}(1-\cos \lambda)}{\sin \lambda} ; \\
D_{\text {вих }}(R o)=0,5 \cdot V_{1} \cdot t_{n}+\sqrt{2 \cdot R_{\text {вив }} \cdot R_{o}+R_{o}^{2}} .
\end{gathered}
$$

Із двох значень, знайдених за рівняннями (1) i (2), приймається більше:

$$
D_{\text {вux }}=\max \left\{D_{\text {вux }}\left(H_{\sigma}\right), D_{\text {вux }}\left(R_{o}\right)\right\} .
$$

На рис. 3 зображено схему розрахунку області бомбометання у вертикальному розрізі. Необхідно отримати 3D модель області бомбометання з урахуванням всіх вище наведених обмежень.

При застосуванні авіаційних засобів ураження великої потужності необхідно враховувати при побудові області бомбометання і проходження ударної хвилі, яка спричинює штучний зсув повітряних мас [12].

Так, для виведення інформації льотчику при виконанні бомбометання необхідно мати не тільки розраховані параметри області бомбометання з урахуванням типу засобів ураження, швидкості літального апарату, густини повітря та кута пікірування, а і необхідно враховувати рельєф місцевості, протидію об'єктової та зональної системи ППО. Причому дана інформація не повинна загромаджувати інформаційне поле льотчика. 


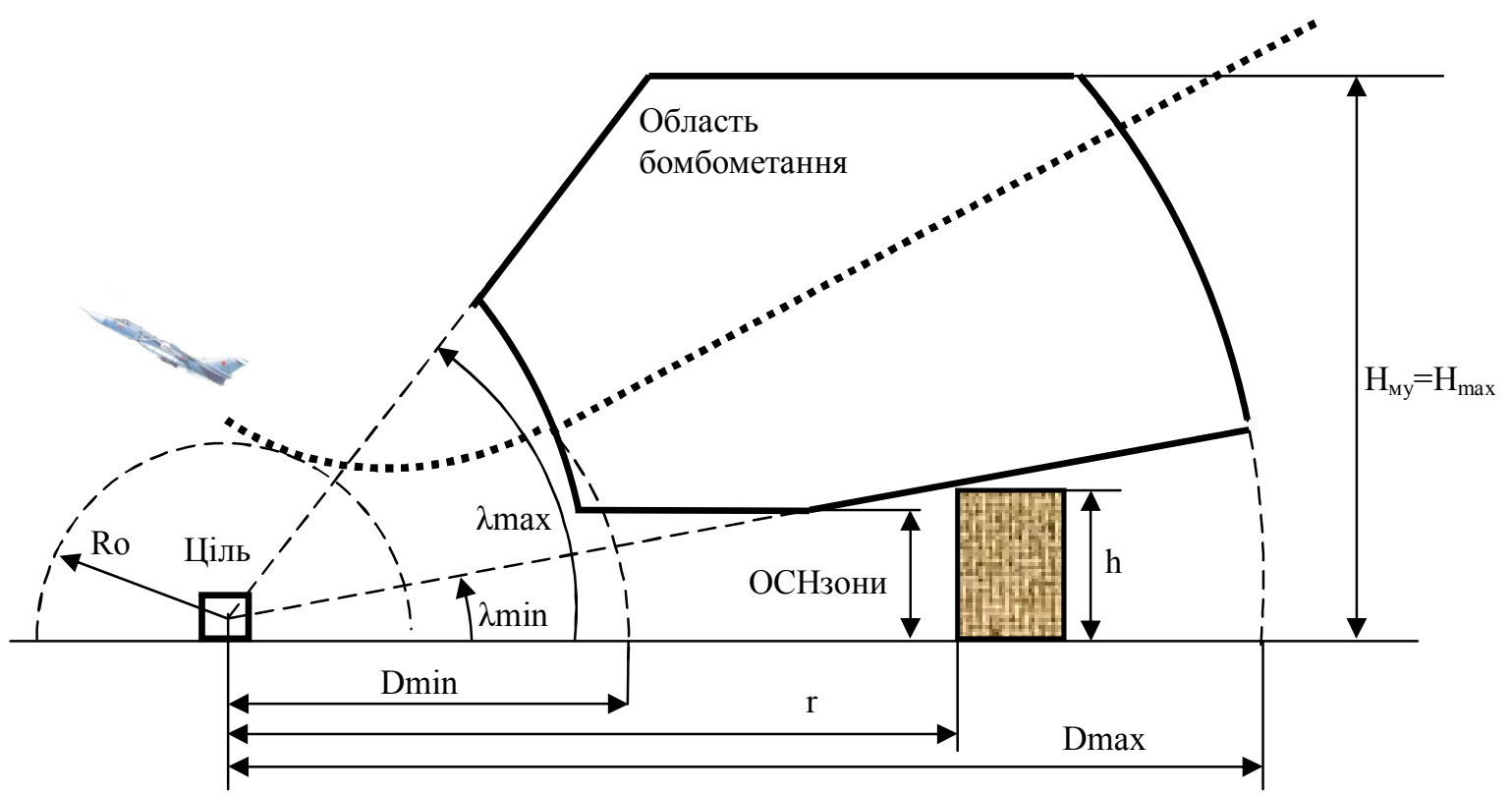

Рис. 3. Розрахунок області виконання бомбометання для літального апарату з урахуванням впливу небезпечних факторів

Одна людина (льотчик), приймаючи рішення про оптимальну траєкторію виходу до цілі і застосуванні зброї, повинна керувати літальним апаратом і використовувати пілотажні, навігаційні, зв'язкові, радіолокаційні і оптоелектронні системи, а також засоби державного впізнання і радіоелектронної боротьби. Крім того, льотчик повинен постійно контролювати виконання бойового завдання на основі інформації, отриманої від бортових розвідувальноприцільних засобів і зовнішніх джерел. Виконати такий обсяг функцій в процесі вирішення різних бойових завдань неможливо без об'єднання перерахованих вище засобів в комплексні інтегровані системи, а також без забезпечення їх взаємодії з льотчиком (екіпажем).

В процесі взаємодії льотчика 3 комплексом бортового обладнання літаків різних поколінь спостерігаються зміни, що обумовлює зміни компонування, структури і характеристик технічного вигляду інформаційно-керуючого поля кабін цих машин.

У міру збільшення складу обладнання та кількості розв'язуваних функціональних завдань необхідно збільшувати ступінь автоматизації роботи обладнання для зменшення навантаження на льотчика. Таким чином, ускладнення системи авіаційного радіоелектронного обладнання повинно супроводжуватися спрощенням роботи льотчика.

\section{Висновки}

Використання даного методу визначення небезпечних зон дії авіаційних засобів ураження, прив'язаних до 3D картографічної інформації в зоні виконання бойового завдання, в програмному продукту дає можливість швидко і точно спланувати нанесення удару літальним апаратом по цілям противника, а також можливість використання в бортових обчислювальних машинах для обчислення і надання льотчику інформації на тактичний дисплей 3 прив'язкою до місцевості чи до повітряної обстановки та зон поразки системи ППО противника в тривимірному просторі.

Забезпечення екіпажу виводом даної інформації в кабіні літака на тактичному дисплеї з прив'язкою до супутникової навігаційної системи дає можливість більш ефективно застосовувати засоби поразки, при цьому не входити в зони поразки своїх засобів і ефективно обходити зони поразки ППО противника.

Побудова даних зон в трьохвимірному просторі повинно базуватися на автоматичному розрахунку зон поразки виходячи 3 фактичних параметрів польоту літака, типу авіаційного засобу поразки та типу ППО противника, які будуть протидіяти в заданому районі нанесення удару.

\section{СПИСОК ЛІТЕРАТУРИ}

1. Наказ МОУ №100 від 23 лютого 2016 року. Правила штурманського забезпечення польотів державної авіації України. http://zakon0.rada.gov.ua/laws/show/z0418-16

2. Афанасьев В.В. Применение компьютера для штурманских расчетов на этапе предварительной подготовки к полету. / Афанасьев В.В. // Системи обробки інформації. - 2006. - Вип. 6. - С.3-8.

3. Онипченко П.М. Напрямки підвищення оперативності і якості бойової підготовки льотного складу авіації ПС ЗС України. / П.М. Онипченко, М.А. Павленко, О.І. Тимочко// Системи обробки інформації. - 2016. - Вип. 3(140). C. 264-266.

4. Сітков О.М. Вибір ділянки корекції координат місцеположення літака з врахуванням геометричного фактору навігаційного поля радіонавігаційних систем. / О.М. Сітков, Ю.В. Афанасьєв // Системи обробки інформації. - 2016. Вип. 3(140). - С. 103-106. 
5. Баханов Л.Е. Системы управления вооружения истребителей. Основы интеллекта многофункционального самолёта. / Л.Е. Баханов, А.Н. Давыдов, В.Н. Корниенко, В.В. Слатин, Е.П. Федосеев, Е.А. Федосов, Б.Е. Федунов, Л.Е. Широков. // М.: Машиностроение, 2005 - 400с.

6. Боровицкий Д. Системы отображения полётной информации: информационноуправляющее поле кабины летательных аппаратов. / Д. Боровицкий // Зарубежное военное обозрение. - 2005. - Вып. 2 - С.42-48.

7. Шамко Є. В. Основні особливості застосування Повітряних Сил в сучасних умовах ведення збройної боротьби / Є. В. Шамко, О. М. Жарик, В. В. Коваль // Наука і техніка Повітряних Сил Збройних Сил України. — 2017. — Вип. 2. — C. $15-18$.

8. Чикуров В.А. Основы боевого применения вооружения фронтовой авиации. / В.А. Чикуров, Н.А. Жук, Ю.С. Хаецкий, А.М. Барбарин, А.А. Давыдов. // Х: ХВВАУЛ, 1994. - 246с.

9. Алімпієв А.М. Особливості гібридної війни РФ проти України. Досвід, що отриманий Повітряними Силами Збройних Сил України / А.М. Алімпієв, Г.В. Пєвцов // Наука і техніка Повітряних Сил Збройних Сил України. — 2017. — Вип. 2. - С. 19-25.

10. Миропольський Ф.П. Методика проведений занятий и выполнения расчётов по определению безопасных условий бомбометания. / Ф.П.Миропольський // Выпуск 189. ВВИОЛОРКА имени Н.Е.Жуковского, - 1978. - 54 с.

11. Наказ МОУ №700 від 09 грудня 2015 року "Про затвердження Правил польотів державної авіації в повітряному просторі України." http://zakon3.rada.gov.ua/laws/show/z1622-15.

12. Колодяжний О.І. Моделювання небезпечних зон впливу штучного зсуву повітряних мас на динаміку руху високоманевреного літака. / О.І. Колодяжний, О.І. Тимочко. // Системи обробки інформації, - 2017. Вип. 1(147). - С. 80-87.

Рецензент: д-р техн. наук, проф. С. В. Козелков, Державний університет телекомунікацій, Київ Received (Надійшла) 28.05.2018

Accepted for publication (Прийнята до друку) 29.07.2018

\section{Формирование информационного поля в кабине боевого самолёта в условиях применения мощных взрывов}

\section{Ю. Б. Ситник, В. В. Стадник}

Повышение многофункциональности и характеристик бортового оборудования, увеличение объемов информации, поступающей на самолет (который в настоящее время можно уже рассматривать как элемент распределенной информационно-ударной системы), а также внешние угрозы, которые могут возникнуть на театре военных действий, предъявляют более высокие требования к отображению информации и компоновке кабин боевых самолетов. Формирование в кабине самолета информационного поля для вывода информации летчику при выполнении боевого задания на бомбометание необходимо иметь не только рассчитанные параметры области бомбометание с учетом типа средств поражения, скорости летательного аппарата, плотности воздуха и угла пикирования, а и необходимо учитывать рельеф местности, противодействие объектовой и зональной системы ПВО. Цель статьи - разработка метода определения параметров опасных зон влияния на летательный аппарат во время выполнения боевого задания, необходимых для предоставления информации летчику в реальном режиме времени на дисплее в кабине самолета. Выводы. Обеспечение экипажа выводом данной информации в кабине самолета на тактическом дисплее с привязкой к спутниковой навигационной системы дает возможность более эффективно применять средства поражения, при этом не входить в зоны поражения своих средств и эффективно обходить зоны поражения ПВО противника. Построение данных зон в трехмерном пространстве должно базироваться на автоматическом расчете зон поражения исходя из фактических параметров полета самолета, типа авиационного средства поражения и типа ПВО противника, будут противодействовать в заданном районе нанесения удара.

Ключевые слов : информационное поле, область бомбометания, условия безопасности, летательный аппарат, зона влияния, искусственный сдвиг воздушных масс.

\section{The information field formation cockpit combat aircraft in the conditions for the application of powerful explosions}

\section{Yu. Sitnik, V. Stadnik}

Increasing the multifunctionality and characteristics of on-board equipment, increasing the amount of information received by the aircraft (which can now be seen as an element of the distributed information-shock system), as well as external threats that may arise at the theater of military action, bring higher requirements for information display and layout of cockpits of combat aircraft. Formation in the cockpit of an information field for the information output of the pilot in the performance of the combat task for bombing must have not only calculated parameters of the area of bombing, taking into account the type of defeat, speed of the aircraft, air density and the angle of dive, but also need to take into account the terrain, counteraction to object and zonal air defense system. With the increase of equipment and the number of solved functional tasks, it is necessary to increase the degree of automation of the equipment to reduce the load on the pilot. Thus, the complication of the aviation ra-dioelectronic equipment system should be accompanied by simplification of the work of the pilot. The purpose of the article is the development of a method for determining the parameters of hazardous areas of influence on the aircraft during the execution of the combat task required to provide information to the pilot in real time mode on the display in the cockpit. Conclusions. The use of this method of determining the non-safe areas of aviation damage, linked to 3D cartographic information in the area of combat task, in the software program allows you to quickly and accurately plan the impact of an aircraft on the objectives of the protagonist. Providing the crew with the output of this information in the cabin of the aircraft on a tactical display with anchoring to the satellite navigation system makes it possible to more effectively use the means of defeat, while not entering the zone of defeat their means and effectively circumvent the areas of defeat enemy air defenses. The construction of these zones in a three-dimensional space should be based on the automatic calculation of the defeat zones based on the actual parameters of the flight of the aircraft, such as the aircraft means of defeat and the type of enemy air defense, which will counteract in the specified area of impact.

Keywords : information field, bombing area, safety conditions, aircraft, impact zone, artificial displacement of air masses. 